\title{
A GIS-based AHP approach for emergency warehouse site selection: A case close to Turkey-Syria border
}

\author{
CihanÇETINKAYA*, ErenÖZCEYLAN** and İlhan KESER*** \\ * Management Information Systems Department, Adana Alparslan Turkes Science and Technology University, Adana, Turkey. \\ ** Department of Industrial Engineering, Gaziantep University, Gaziantep, Turkey. \\ *** Disaster and Emergency Management Presidency of Gaziantep Branch, Gaziantep, Turkey. \\ *Corresponding Author: cihancetinkaya1903@hotmail.com
}

Submitted :23/05/2020

Revised : :31/05/2021

Accepted :09/06/2021

\begin{abstract}
Although the term "disaster" includes natural events like earthquake, flood, and drought, it also covers the wars, intense migration waves, industrial accidents, and even epidemic diseases. In recent years, the number and severity of both natural and man-made disasters has been increasing. In this context Gaziantep-the border city of Turkey to Syria-is facing many logistical problems because of the crisis in the region that has a broad repercussion in press. In addition, the coronavirus pandemic increased the supply traffic in the region. The region is in need for many emergency warehouses to store the emergency supplies and send to the needy. Thus, a three-step hybrid solution method is developed to solve this real life problem. The first stage is the determination of selection criteria; secondly the spatial database is created by using a Geographical Information System (GIS). Then, Analytic Hierarchy Process (AHP) technique is applied to assign the importance levels to the selection criteria to generate the suitability map to choose the most appropriate emergency warehouse site selection in Gaziantep. Additionally, scenario analyses are conducted to understand the effects of importance levels on the problem results. As a result, $1.3 \%$ of the study area is determined as "quite suitable" for establishing an emergency warehouse.
\end{abstract}

Keywords: AHP; Case study; Coronavirus; Emergency warehouse; GIS; Site selection.

\section{INTRODUCTION}

The urgent necessity during disasters is to save lives, reduce suffering, damage, and losses, and to protect, comfort, and support affected people. While life-saving responses and speed must be the priority aim for emergency operations, also minimizing the adverse ecological impacts on the environment is still important (IFRC, 2020). Recently, the number of devastating disasters has increased throughout the world. Lastly, the world faced a devastating coronavirus pandemic that totally halted the normal life (WHO, 2020). The sufferings, casualties, and social problems after any type of disasters increase the importance level of preparedness for the disasters. In this scheme, determining the locations of emergency warehouses is crucial, and it can be classified as an important post disaster relief operation (Amiri and Asvadi, 2015). 
Turkey has been a victim of all types of disasters in the history (Kemaloglu, 2015). Thus, emergency warehouses have been established in 25 provinces of Turkey to name the cities; Adana, Adiyaman, Afyon, Aksaray, Ankara, Antalya, Bursa, Denizli, Diyarbakir, Duzce, Elazig, Erzincan, Erzurum, Manisa, Kahramanmaras, Kastamonu, Kirikkale, Kocaeli, Mugla, Mus, Samsun, Sivas, Tekirdag, Van, and Yalova. While these warehouses can be seen on the map below in Figure 1, their external view is given in Figure 2.

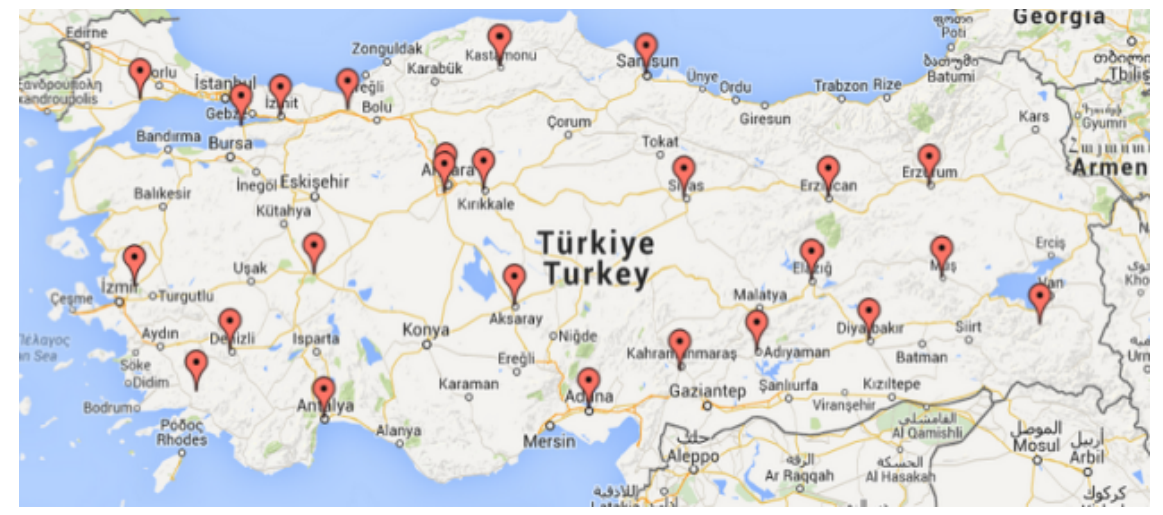

Figure Error! No text of specified style in document.. Emergency warehouses in Turkey (AYDES, 2019).

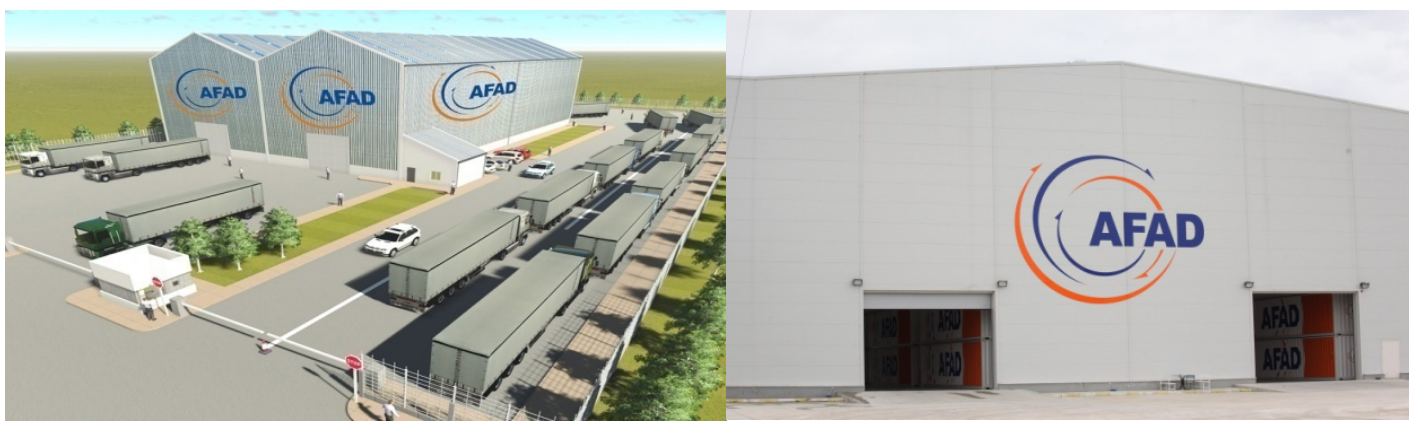

Figure 2. External view of the emergency warehouses.

Since 2011, Syria is facing an internal turmoil and there is a big logistics flow from all over the world to the area. Gaziantep is the closest border city of Turkey to the turmoil region resulting in giant logistics activities. In addition, there is a high earthquake risk of the city, especially in Nurdagi and Islahiye (western) districts. In this regard, the Turkish government plans to establish an emergency warehouse to the city to deliver humanitarian aid from Turkey to the affected people in Syria quickly and at low cost. Also it will be possible to improve the earthquake preparedness with the emergency warehouse. By determining an appropriate emergency warehouse, both transportation cost minimization and ecological adverse effects minimization could be reached. Since the nature of the site selection problem includes multiple criteria to take into account, multicriteria decision making (MCDM) techniques are very suitable for solving these types of problems (Lotfi et al., 2017). In addition, GIS is very effective to make use of the criteria containing spatial data.

Thus, a scientific decision making methodology is proposed in this study to determine the potential locations for emergency warehouses for Gaziantep. In this regard, a three-step approach is developed. Firstly, three main criteria (location, disaster, and land structure related criteria) and 11 subcriteria are determined by the help of literature (Roh et al., 2013) and experts from Prime Minister's Disaster and Emergency Management Presidency 
(DEMP) and related data are obtained. Secondly, the spatial data of each criterion is mapped by using GIS software to determine an availability score to potential locations. Lastly, indicators are prioritized by using the AHP to generate a suitability map.

The paper is organized as follows. The next section provides a literature review on GIS-based MCDM in disaster management and also the site selection problems that are solved with GIS-based AHP method. Section 3 gives information about the applied methodologies. Description of the case study and results with scenario analysis are presented in Section 4. The last section gives the summarized conclusion and leads for future studies.

\section{LITERATURE REVIEW}

Since the importance of emergency warehouse site selection problem is very high, it is examined frequently by the researchers in the literature. But, to the best of authors' knowledge, there is no study in the literature that uses GIS-based AHP approach for determining the suitable locations for emergency warehouses. Thus, in this part of the study, the papers that examine the emergency warehouse site selection problem are summarized.

An emergency logistics center site selection problem is proposed by Turğut et al. (2011) to be used for possible earthquake victims. They used AHP and fuzzy AHP for site selection, and a case study is examined for Istanbul, which is the most crowded city of Turkey. The reason for fuzzy AHP model was to cope with the uncertainties arising from the nature of human judgment. They determined the selection criteria by applying questionnaires to specialists from Istanbul Center of Disaster Coordination and from the literature. Their results determined by both methods pointed out the same alternative, but with different weights, and, namely, the "Kartal" alternative was selected as the most appropriate location for emergency logistics center in İstanbul.

A shelter site selection problem for Turkish Red Crescent is examined by Kilc1 (2012). Firstly, they determined the potential shelter site locations, and they ranked these potential locations by using a weighted average function composed of eleven criteria. In case of an emergency, these locations are utilized starting from the highest ranking. To improve the Turkish Red Crescent's method, a mathematical model is developed that chooses the best possible combination of shelter sites from a set of potential locations, controls the utilization of these sites, and assigns every district to the closest shelter site. Emergency material warehouse site selection problem is examined by Liu et al. (2013). They modeled the problem as a fuzzy programming model, and the model was transformed into biobjective mixed integer programming model by using the theories of fuzzy numbers. Then, a heuristic algorithm was proposed for the model. Later, the algorithm was tested on a numerical example and it was proven to be feasible and effective.

A decision support system is proposed for relief logistics center site selection problem by Amiri and Asvadi (2015). They considered the risk, availability, technical, cost, and coverage issues, and they used AHP technique to solve the problem. For obtaining pairwise comparisons of the criteria and alternatives, they used two decision making methods, namely, lexicographic goal programming, and two-step logarithmic goal programming. Finally, they tested their model on a case study in Tehran, Iran.

Boltürk et al. (2016) examined the humanitarian logistics (HL) warehouse location selection problem. They used hesitant fuzzy sets to cope with the uncertainty of problem nature, and they made use of fuzzy AHP method to solve the problem. They had five main criteria and 16 subcriteria, and they evaluated five different potential locations. A case study on a Turkish humanitarian relief organization was conducted to prove the effectiveness of the method. 
Trivedi and Singh (2017) proposed a hybrid decision support approach for emergency shelter site selection problem. They identified six selection criteria by the help of literature and as a result of their consultation from disaster management experts. Fuzzy AHP and TOPSIS techniques are used to prioritize the selection criteria and to rank the potential emergency shelter locations. Finally, a case study is conducted on Nepal earthquake to prove the effectiveness of the model.

Timperio et al. (2017) proposed a decision support framework for disaster logistics network design. They used eight criteria for site selection, and they made use of fuzzy AHP technique. Their most important criterion was found as "access to affected zones". They evaluated 21 locations in total in different cities of Indonesia, and as a result they proposed six distribution centers to be opened. Roh et al. (2018) proposed a two-step methodology by using fuzzy AHP and fuzzy TOPSIS to evaluate the potential emergency warehouse locations for humanitarian relief organizations. They made use of five main criteria and 25 subcriteria for evaluating the potential locations. They determined the national stability criteria as the most important one for selecting the most appropriate location.

Dhia (2020) examined the emergency warehouse site selection problem in Padang City, Indonesia. For problem solution, AHP and Comparative Performance Index (CPI) method were used together. First, five-site selection criteria were determined from the literature and interviews with experts, then the alternative warehouse locations were defined. Criteria weights were determined by using Analytical Hierarchy Process, and the CPI method was used for ranking the alternative locations. As a result, Balai Gadang village was determined as the best location for a disaster logistics warehouse in Padang City. Table 1 represents a brief review of the aforementioned papers. According to Table 1, it is clear to see that the most the applied methodology is AHP that is also used in our paper. The main difference of our study from the literature is considering an emergency warehouse site selection problem arising at Turkey and Syrian border.

Table 1. A brief review of literature.

\begin{tabular}{|c|c|c|c|}
\hline Reference & Problem & Methodology & Case \\
\hline Turğut et al. (2011) & $\begin{array}{l}\text { Emergency logistics center site } \\
\text { selection }\end{array}$ & Fuzzy AHP & İstanbul, Turkey \\
\hline Kılc1 (2012) & Shelter site selection & Mathematical modeling & İstanbul, Turkey \\
\hline Liu et al. (2013) & $\begin{array}{l}\text { Emergency material warehouse } \\
\text { site selection }\end{array}$ & $\begin{array}{l}\text { Fuzzy mathematical } \\
\text { modeling }\end{array}$ & Numerical example \\
\hline $\begin{array}{l}\text { Amiri and Asvadi } \\
(2015)\end{array}$ & $\begin{array}{l}\text { Relief logistics center site } \\
\text { selection }\end{array}$ & AHP & Tehran, Iran \\
\hline $\begin{array}{l}\text { Boltürk et al. } \\
(2016)\end{array}$ & $\begin{array}{l}\text { Humanitarian logistics warehouse } \\
\text { site selection }\end{array}$ & Hesitant fuzzy AHP & $\begin{array}{l}\text { Marmara Region of } \\
\text { Turkey }\end{array}$ \\
\hline $\begin{array}{l}\text { Trivedi and Singh } \\
(2017)\end{array}$ & Emergency shelter site selection & Fuzzy AHP and TOPSIS & Nepal Earthquake \\
\hline $\begin{array}{l}\text { Timperio et al. } \\
(2017)\end{array}$ & $\begin{array}{l}\text { Relief logistics center site } \\
\text { selection }\end{array}$ & GIS-based Fuzzy AHP & $\begin{array}{l}\text { Different cities in } \\
\text { Indonesia }\end{array}$ \\
\hline Roh et al. (2018) & $\begin{array}{l}\text { Emergency warehouse site } \\
\text { selection }\end{array}$ & $\begin{array}{l}\text { Fuzzy AHP and Fuzzy } \\
\text { TOPSIS }\end{array}$ & Numerical example \\
\hline Dhia (2020) & $\begin{array}{l}\text { Emergency warehouse site } \\
\text { selection }\end{array}$ & AHP & Padang, Indonesia \\
\hline This paper & $\begin{array}{l}\text { Emergency warehouse site } \\
\text { selection }\end{array}$ & GIS-based AHP & $\begin{array}{l}\text { Gaziantep (Syrian } \\
\text { border), Turkey }\end{array}$ \\
\hline
\end{tabular}


In addition to the mentioned papers above, the reader is referred to Ma et al. (2019) for a view of methodological and case-study based papers in site selection models in natural disaster shelters. In the review study, the papers are classified based on their types, constraints, objectives, and solution methods. They classified the papers according to the objective and hierarchy types as follows: single objective models, multiobjective models, and lastly the hierarchical models. As for the objectives of the proposed models, they determined generally minimization models. Mostly, the proposed models try to minimize the evacuation time or distance, warehouse or shelter construction numbers or costs, and finally the total risk. Both intelligent optimization algorithms and GIS are used for the solution of the problems. For future studies, they offer to work on determining the shelter locations of multiple disasters on real case studies.

This paper contributes to the literature by proposing a GIS-based AHP approach for determining the locations of emergency warehouses by using three main criteria and 11 subcriteria. Also, the method is applied on an emergency risk prone region as a case study. In addition to the scientific pros, it also tries to help the policy makers on real life problems.

\section{METHODOLOGY}

In this paper, a GIS-based AHP approach is applied to evaluate the potential sites for an emergency warehouse establishment. In this part of the paper, firstly a brief explanation about GIS and AHP is given followed by the proposed hybrid approach.

\subsection{GIS}

GIS is an information system that integrates functions such as data collection, storage, and analysis. GIS, which is rooted in Geography, consists of a combination of many data types. GIS provides the visualization of maps and 3D scenes by organizing layers of information together with the analysis of spatial locations entering all areas of our lives. With this unique capability, GIS provides the user with a deeper insight by making cross-data modeling and relationship to help users make smarter decisions (ESRI, 2020). Figure 3 shows a simple example of the data set structure in GIS.

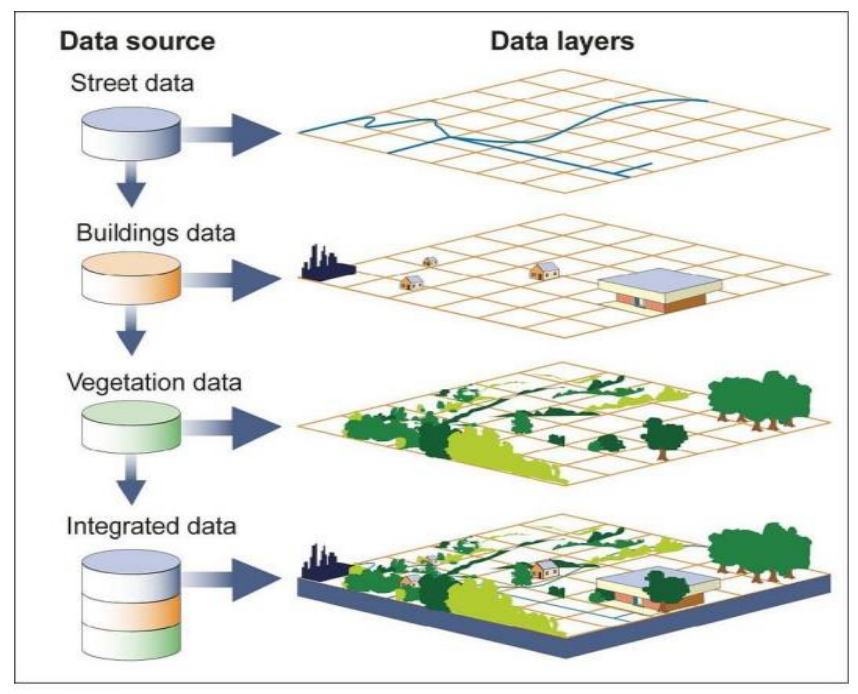

Figure 3. Simple example of dataset structure. 
GIS is used frequently as an effective tool for site selection problems (Karimi, 2019). Thus, in this paper, the outcomes of this effective tool are obtained. Figure 4 includes the analyses that are conducted by GIS for this study.

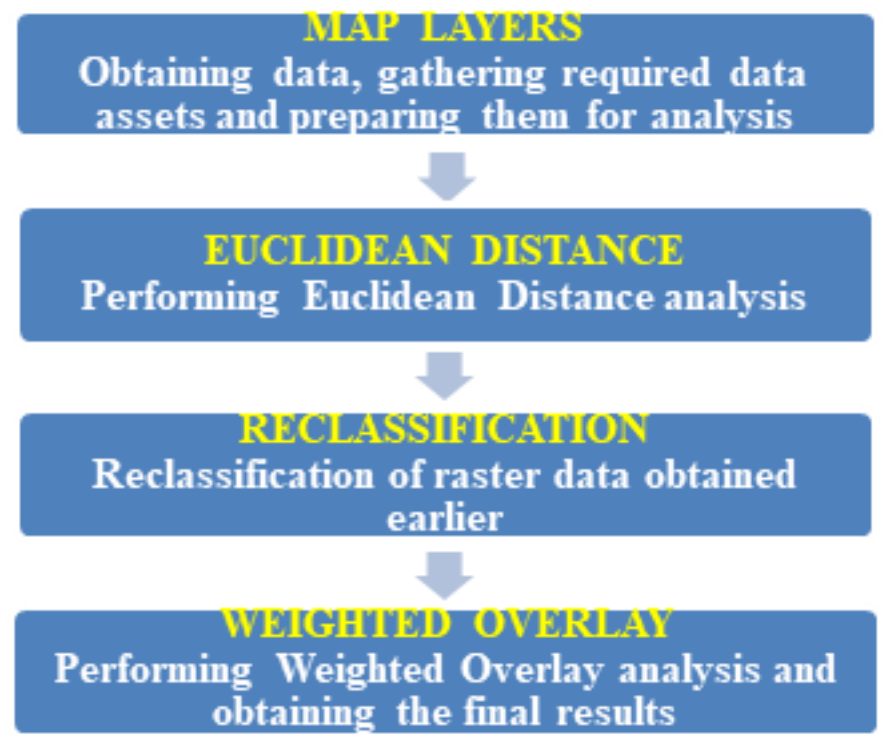

Figure 4. GIS analysis steps.

Although GIS is an effective tool used for site selection problems, it is much more effective when combined by an MCDM technique (Malczewski, 2006). Thus, AHP is chosen to support GIS in the analyses. Next part gives information about the AHP technique.

\subsection{AHP}

The AHP technique developed by Saaty in the 1970s is a practical MCDM technique that analyzes and solves complex decision problems (Saaty, 1980). It can be used to determine criteria weights or priorities and sort alternatives depending on quantitative and qualitative assessments. Alternatively, AHP can be applied only to determine criteria weights or priorities and act as a support for other MCDM techniques, which require criteria weights. The primary advantages of the AHP method applied by the authors are as follows (Ishizaka and Labib, 2009).

i. It illustrates how possible changes in priority at upper levels influence the priority of criteria at lower levels.

ii. Its stability and flexibility regarding changes within, and additions to, the hierarchy are shown.

iii. The values of the weight coefficients obtained using AHP are reliable owing to the consideration of a consistency ratio in the calculation of the weight coefficients.

iv. In this study, the criteria weights determined by the AHP technique were used to construct the suitability map for the potential emergency warehouse sites. Details of the AHP method are given below (Saaty, 1980; Subramanian and Ramanathan, 2012):

Step\# 1 : In the first level, a goal is defined as to rank the potential sites for an emergency warehouse installation. The second level represents the criteria for the study.

Step\# 2 : To assign the criteria weights, a pairwise comparison matrix (matrix A (Eq. (1)) is arranged. Pairwise comparison decisions are performed on the basis of predefined rating value of nine levels (Table 2). 
Table 2. Table of importance scale used in pairwise comparison (Saaty, 1980).

\begin{tabular}{|c|c|c|}
\hline Intensity & Definition & Explanation \\
\hline 1 & Equal importance & Two barriers contribute equally to the goal \\
\hline 3 & Moderate importance & Experience and judgment slightly favor one over the other \\
\hline 5 & Essential or strong importance & Experience and judgment strongly favor one over the other \\
\hline 7 & Demonstrated importance & Dominance of the demonstrated in practice \\
\hline 9 & Extreme importance & $\begin{array}{c}\text { Evidence favoring one over the other of highest possible order } \\
\text { of affirmation }\end{array}$ \\
\hline $2,4,6,8$ & Intermediate values & \begin{tabular}{c} 
When compromise is needed \\
\hline
\end{tabular}
\end{tabular}

Assuming $\mathrm{n}$ is criteria, the pairwise comparison of criterion $\mathrm{i}$ with criterion $\mathrm{j}$ yields a square matrix $\mathrm{A}$, where $a_{i j}$ denotes the relative importance of criterion $\mathrm{i}$ with respect to criterion $\mathrm{j}$. In the matrix, $a_{i j}=1$ when $i=j$ and $a_{j i}=1 / a_{i j}$.

$$
A_{n x n}=\left[\begin{array}{cccc}
1 & a_{12} & \cdots & a_{1 n} \\
a_{21} & 1 & \cdots & a_{2 n} \\
\cdots & \cdots & \cdots & \cdots \\
a_{n 1} & a_{n 2} & \cdots & a_{n n}
\end{array}\right]
$$

Step\#3 : Construct a standardized matrix as per Eq. (2) as follows:

$c_{i j}=\frac{a_{i j}}{\sum_{j=1}^{n} a_{i j}}$, where $i=1,2,3, \ldots, m$ and $j=1,2,3, \ldots, n$

Step\#4 : Construct the row sum and the weightage for each criterion as per Eq. (3):

$w_{i}=\frac{1}{n} \sum_{j=1}^{n} c_{i j}, i=1,2,3, \ldots, m$

Step\# 5 : The priority vector is calculated using $V_{i}=A x w_{i}$, for $i=1,2,3, \ldots, m$.

Step\# 6 : The eigenvector $\lambda_{i}=\frac{v_{i}}{w_{i}}$, is calculated, and the principal eigenvalue $\lambda_{\text {max }}$ is determined.

Step\# 7 : Consistency index (CI) is calculated using Eq. (4)

$C I=\frac{\lambda_{\max }-n}{n-1}$

(4)

Step\#8 : Consistency ratio (CR) is obtained by Eq. (5). The value of the random inconsistency index (RI) depends on RI values corresponding to the value $\mathrm{n}$ shown in Table 3.

$$
C R=\frac{C I}{R I}
$$


Table 3. Random inconsistency index $(R I)$.

\begin{tabular}{|c|c|c|c|c|c|c|c|c|c|c|c|c|c|c|c|}
\hline $\boldsymbol{n}$ & $\mathbf{1}$ & $\mathbf{2}$ & $\mathbf{3}$ & $\mathbf{4}$ & $\mathbf{5}$ & $\mathbf{6}$ & $\mathbf{7}$ & $\mathbf{8}$ & $\mathbf{9}$ & $\mathbf{1 0}$ & $\mathbf{1 1}$ & $\mathbf{1 2}$ & $\mathbf{1 3}$ & $\mathbf{1 4}$ & $\mathbf{1 5}$ \\
\hline $\boldsymbol{R I}$ & 0.00 & 0.00 & 0.58 & 0.90 & 1.12 & 1.24 & 1.32 & 1.41 & 1.45 & 1.49 & 1.51 & 1.48 & 1.56 & 1.57 & 1.59 \\
\hline
\end{tabular}

The CR value should be less than $10 \%$ to be acceptable. If the value of $\mathrm{CR}$ is greater than 0.10 , it can be interpreted as pairwise comparisons that are inconsistent, or there is a calculation error. In this case, the comparisons should be reviewed again (Achu et al., 2020). In the application phase, expert choice package program is used to make the required AHP calculations.

\subsection{Proposed Approach}

In this study, the aforementioned two approaches are combined. With the AHP approach, which is one of popular MCDM methods, the criteria weights for the site selection are determined. Then, the criteria are put into the layer analysis within ArcGIS 10.2 software to create the suitability map. After determining the suitability map, emergency warehouse sites are determined. The applied methodology is given in Figure 5.

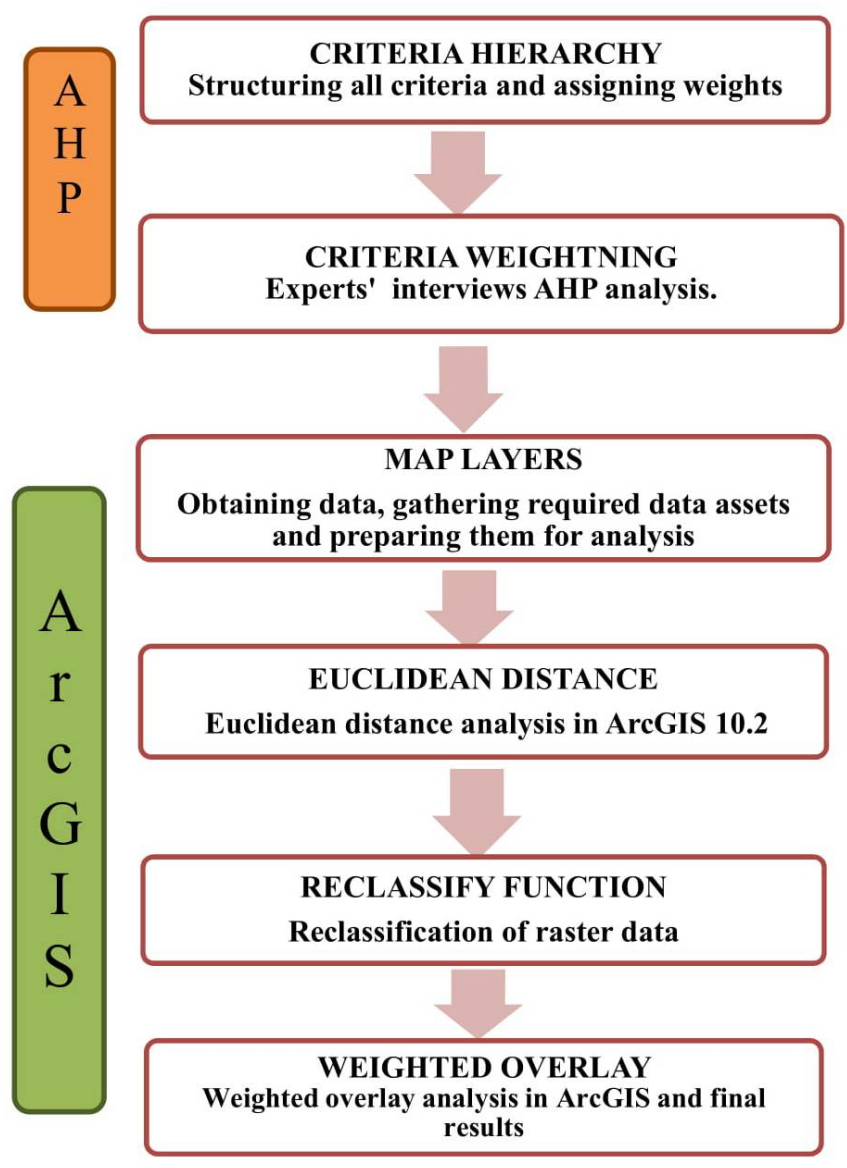

Figure 5. Applied methodology process. 


\section{CASE OF GAZIANTEP}

In this section, we present an application of the solution method on a case study arising in Gaziantep, a city on Turkey-Syria border, in Turkey. We will first describe the case study in more detail, including the input data used, and then present the associated results obtained.

\subsection{Study Area}

The study area is Gaziantep province that covers an area of $6,794 \mathrm{~km}^{2}$. The population of Gaziantep is 2.028.563 according to the results of 2018 address based population registration system (TSI, 2018). The proportion of residents in the city center is $88.7 \%$, while the proportion of residents in the village is $11.3 \%$. Gaziantep province is divided into 9 districts. The largest districts regarding population are Sahinbey, Sehitkamil, and Nizip. The smallest district in terms of population is Karkamis, respectively. In Figure 6, Gaziantep province can be seen on open street map.

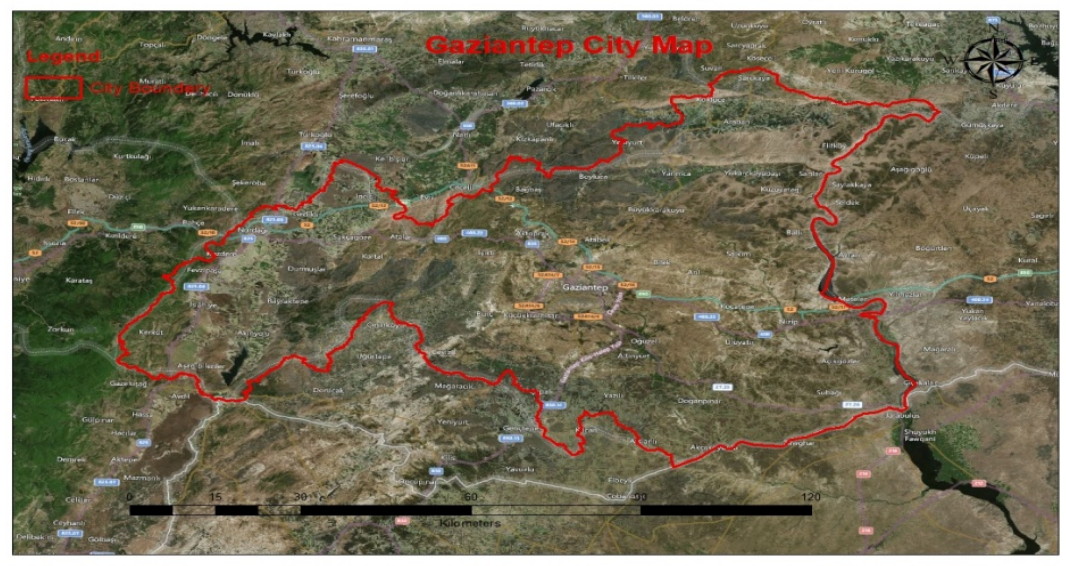

Figure 6. Gaziantep province open street map

There are several reasons for the selection of Gaziantep province in this study. Firstly, the center of Gaziantep province does not take place on any active fault. However, the earthquake risks of Nurdagi and Islahiye districts are very high and the earthquake risk map of Turkey is given in Figure 7 (DEMP, 2020).

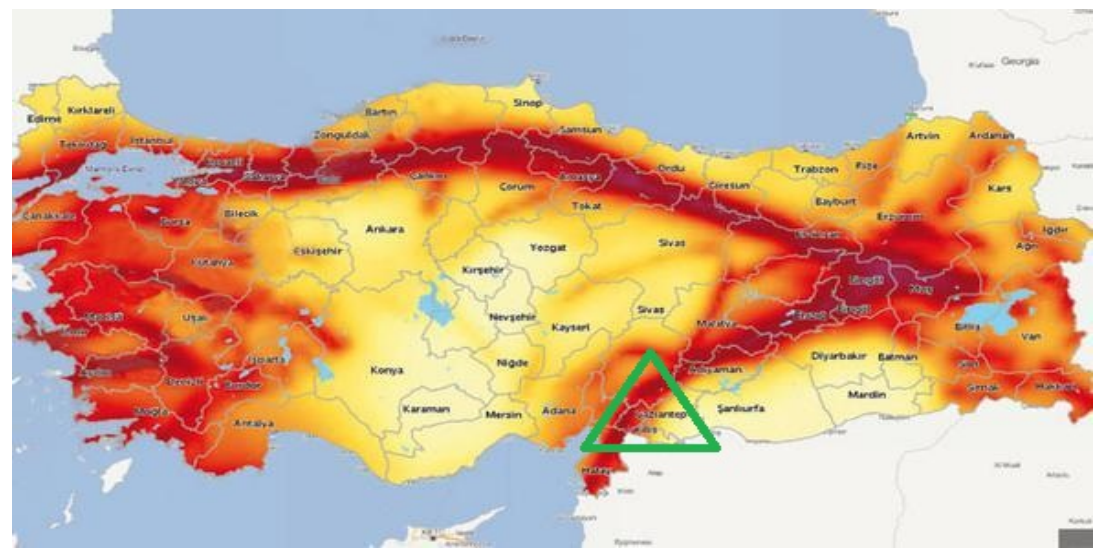

Figure 7. Earthquake risk map of Turkey (DEMP, 2020) 
In addition, as a result of internal turmoil in Syria, it is envisaged to establish a disaster logistics warehouse in order to alleviate the damages and meet the needs of Syrian citizens who came to Gaziantep city since March 2012. Also, Gaziantep is a very important place in Turkey's industry and trade as it is one of the most developed cities in the Southeastern Anatolia region and the most populated metropolitan area between Turkey's southeastern Anatolia and the Mediterranean region. Also Gaziantep is located between Anatolia and the Middle East; it is close to the port towns and to the Silk Road.

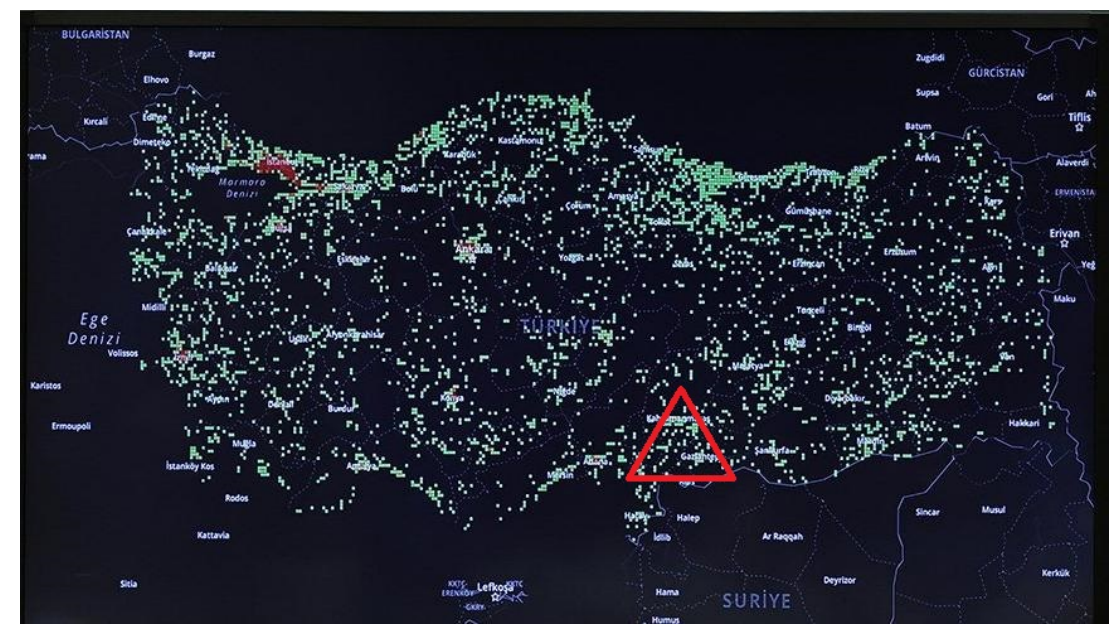

Figure 8. Coronavirus risk map of Turkey (Covid Turkey, 2020).

Lastly, the coronavirus map of Turkey is given in Figure 8. As can be seen, Gaziantep province is one of the riskiest areas in its region. In summary, the study area is very important for Turkey in case of political, commercial, and disaster perspectives.

\subsection{Selection Criteria}

The criteria in the decision-making process are measurable values that characterize the area related to the problem that is used to determine the most appropriate alternatives and to reach a judgment. In this study, the selection criteria of emergency warehouse are determined according to the opinions of DEMP seven experts taking into account the characteristics of the region and the literature studies. A total of 11 sub-criteria under three main criteria are determined for the study. The AHP hierarchy model is given in Figure 9, and the explanation of each criterion is given below.

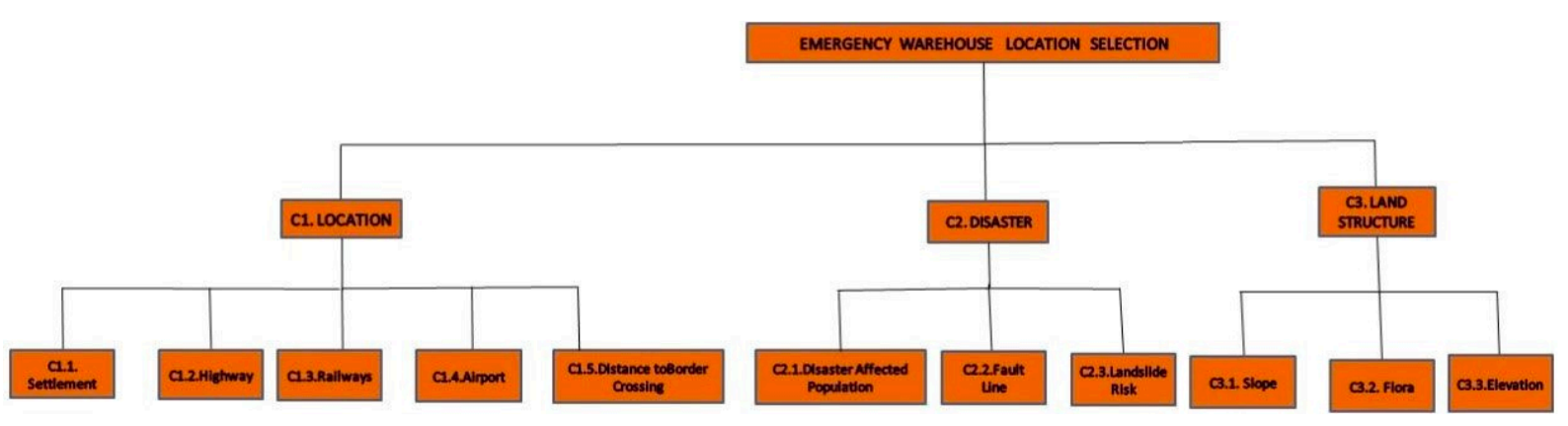

Figure 9. AHP hierarchy model. 
C1. Location: This main criterion is including all subcriteria which are directly related to the geographical location of the emergency warehouse.

C1.1. Settlement distance: Emergency warehouse location to be selected should be close to the settlement.

C1.2. Highway distance: In order to transport the materials to the desired location in a short time and with less cost, the location of the emergency warehouse should be close to the highways.

C1.3. Railways distance: In order to transport the materials to the desired location in a short time and with the lower cost, the location of the emergency warehouse should be close to the railways.

C1.4. Airport distance: Emergency warehouse location should be close enough to the airport in order to reach the desired materials in a short time.

C1.5. Distance to border crossings: In order to deliver humanitarian supplies that may be needed in Syria in a short period of time, the emergency warehouse location to be selected should be located close enough to the border gate.

C2. Disaster: This main criterion is including all subcriteria which are directly related to the effects of potential disasters.

C2.1. Proximity to disaster affected population. Emergency warehouse location to be selected should be close to the proximity to disaster affected population.

C2.2. Distance to fault line: The area where the emergency warehouse will be established should be at a sufficient distance from the fault line.

C2.3. Landslide risk: Emergency warehouse to be installed should be away from the areas of landslide risk.

C3. Land Structure: This main criterion is including all subcriteria which are directly related to the properties of the land affect the emergency warehouse.

C3.1. Slope: Due to the fact that construction cost will be higher in high slope areas, the slope percentage of the area where the emergency warehouse will be installed needs to be low.

C3.2. Flora: The vegetation density of the area where emergency warehouse will be established needs to be low.

C3.3. Elevation: The area where the emergency warehouse will be established needs to have a low elevation.

Table 4. Site selection criteria and references.

\begin{tabular}{|c|c|}
\hline Criteria & Reference \\
\hline C1.1. Settlement distance & Ocampo et al. (2020) \\
\hline C1.2. Highway distance & Lotfi et al.(2018) \\
\hline C1.3. Railways distance & Cetinkaya et al. (2016) \\
\hline C1.4. Airport distance & Ocampo et al. (2020) \\
\hline C1.5. Distance to border crossings & Authors \\
\hline C2.1. Proximity to disaster affected population & Cetinkaya et al. (2016) \\
\hline C2.2. Distance to fault line & He et al. (2017) \\
\hline C2.3. Landslide risk & He et al. (2017) \\
\hline C3.1. Slope & Cetinkaya et al. (2016) \\
\hline C3.2. Flora & Song et al. (2019) \\
\hline C3.3. Elevation & Cetinkaya et al. (2016) \\
\hline
\end{tabular}

In Table 4, the site selection criteria are given with their references. 


\subsection{Prioritization of the Criteria}

Each criterion requires a certain weight to perform overlay analysis in ArcGIS. The weights of each main criterion and subcriteria are calculated using the Expert Choice 11 program. Three main criteria and eleven subcriteria are used for the calculation process. These matrices were prepared through the significance scale used in binary comparison established according to Table 2 as a result of the opinions of seven experts working in emergency warehouse location selection in DEMP. It must be noted that geometric mean is calculated to consider the opinions of seven experts. Pairwise matrix with respect to location main criterion is only shown as an example (Figure 10). The other pairwise matrixes are created in the similar manner. All pairwise matrices are available upon request.

Compare the relative importance with respect to: LOCATION

\begin{tabular}{|c|c|c|c|c|c|}
\hline & \multicolumn{5}{|c|}{ Settlement Highway D Railways D Airport Dis Distance to } \\
\hline Settlement Distance & & 3,0 & 3,0 & 3,0 & 5,0 \\
\hline Highway Distance & & & 5,0 & 5,0 & 7,0 \\
\hline Railways Distance & & & & 1,0 & 3,0 \\
\hline Airport Distance & & & & & 3,0 \\
\hline Distance to Border Crossings & Incon: 0,03 & & & & \\
\hline
\end{tabular}

Figure 10. Pairwise matrix with respect to location main criterion.

The weights of each main criterion and subcriteria are calculated using the pairwise comparison matrixes. The inconsistency ratios of the pairwise comparison matrix are found lower than 0.10 . The results obtained by using the Expert Choice 11 program are shown in Figures 11 and 12.

\begin{tabular}{|c|c|c|c|}
\hline $\begin{array}{r}\text { Priorities with } \\
\text { DISASTER LOGISTICS WAREHO }\end{array}$ & & $\begin{array}{r}\text { Priorities with } \\
\text { DISASTER LOGISTICS WAREHO } \\
\text { >LOCATION }\end{array}$ & \\
\hline LOCATION & 309 & Highway Distance &, 504 \\
\hline DISASTER & 582 & Settlement Distance & 245 \\
\hline LAND STRUCTURE & 109 & Railways Distance & , 102 \\
\hline Thencistency - $00035 ?$ & 1 & |Airport Distance & 102 \\
\hline Inconsistency $=0,00352$ & & Distance to Border Crossings &, 046 \\
\hline with 0 missing judgments. & & Inconsistency $=0,03$ & \\
\hline Structural Adjust is On & & with 0 missing judgments. & \\
\hline
\end{tabular}

Figure 11. Weight of main criteria (left) and location subcriteria (right).

\begin{tabular}{|l||l|l|l|l|}
\hline \multicolumn{1}{|c|}{ Priorities with respect to: } & \multicolumn{3}{c|}{ Priorities with respect to: } \\
DISASTER LOGISTICS WAREHOUSE LOCATION SELECTION \\
$>$ DOISASTER
\end{tabular}

Figure 12. Weight of disaster subcriteria (left) and land structure subcriteria (right). 
The global weights of 11 subcriteria are summarized in Figure 13. According to Figure 13, the most important criterion is determined as the fault line with $25.8 \%$, followed by proximity to disaster affected population (22.5\%) and highway distance $(15.6 \%)$. Due to the fact that places close to the fault line will be affected more in an earthquake that may occur in Gaziantep province, it is vital that the area where the emergency warehouse will be established is located at a sufficient distance from the fault line. Therefore, it is considered as the most important criterion by the experts.

Distance to Fault Line
Proximity to Disaster Affected Population
Highway Distance
Landslide Risk
Settlement Distance
Slope
Railways Distance
Airport Distance
Elevation
Distance to Border Crossings
Flora

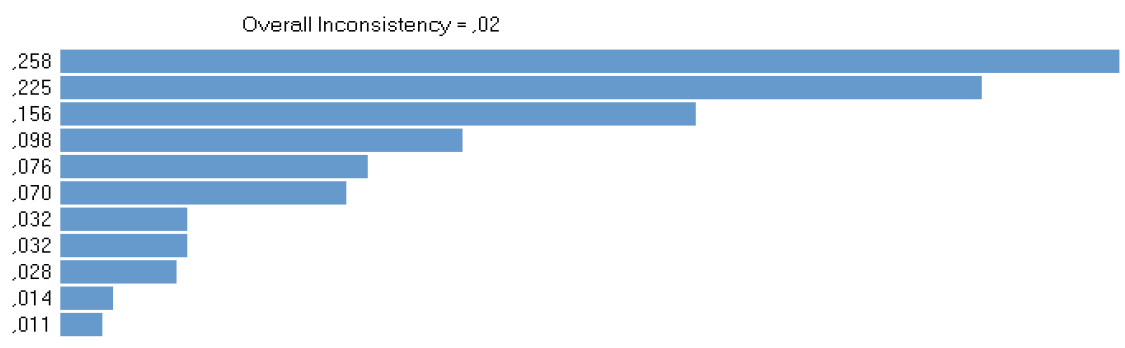

Figure 13. Global weights of 11 criteria.

Assessing the obtained results, the vegetation density of the area where the emergency warehouse will be established was determined as the least important subcriterion by $1.1 \%$.

\subsection{Criteria Layers and Suitability Map}

The list of map layers required for the study is shown in Table 5. For each subcriterion, a separate map layer is created which are downloaded from open sources or drawn based on the existing maps online. Specifically, for the study, raster data has been transformed and analyzed. These map layers, created from raster files, are directly plotted as feature data extensions in the ArcGIS 10.2 software.

Table 5. Sources of criteria maps.

\begin{tabular}{|l|l|l|}
\hline Subcriteria & Map Needed & Source \\
\hline C1.1. Settlement distance & $\begin{array}{l}\text { Map of Gaziantep city center, Islahiye, and } \\
\text { Nurdagi district centers }\end{array}$ & $\begin{array}{l}\text { Metropolitan Municipality of } \\
\text { Gaziantep }\end{array}$ \\
\hline C1.2. Highway distance & $\begin{array}{l}\text { Gaziantep province map of highway } \\
\text { network }\end{array}$ & $\begin{array}{l}\text { General Directorate of } \\
\text { Highways }\end{array}$ \\
\hline C1.3. Railways distance & $\begin{array}{l}\text { Gaziantep province map of railways } \\
\text { network }\end{array}$ & $\begin{array}{l}\text { General Directorate of State } \\
\text { Railways }\end{array}$ \\
\hline C1.4. Airport distance & Map of airport in the region & $\begin{array}{l}\text { Created Using Google Earth } \\
\text { Maps }\end{array}$ \\
\hline $\begin{array}{l}\text { C1.5. Distance to border } \\
\text { crossings }\end{array}$ & Created Using Google Earth Maps & $\begin{array}{l}\text { Created Using Google Earth } \\
\text { Maps }\end{array}$ \\
\hline $\begin{array}{l}\text { C2.1. } \text { Proximity to disaster } \\
\text { affected population }\end{array}$ & $\begin{array}{l}\text { Map of Gaziantep city center, Islahiye, and } \\
\text { Nurdagi district centers }\end{array}$ & $\begin{array}{l}\text { Geographic Map of } \\
\text { Gaziantep Region }\end{array}$ \\
\hline C2.2. Distance to fault line & Gaziantep province fault line map & (DEMP, 2019d) \\
\hline
\end{tabular}




\begin{tabular}{|l|l|l|}
\hline C2.3. Landslide risk & Gaziantep province landslide risk map & (Gaziantep DEMP, 2019a) \\
\hline C3.1. Slope & Gaziantep province slope map & (ASTER GDEM, 2019) \\
\hline C3.2. Flora & Gaziantep province flora map & (Gaziantep DEMP, 2019b) \\
\hline C3.3. Elevation & Gaziantep province elevation map & (ASTER GDEM, 2019) \\
\hline
\end{tabular}

The weights of the criteria for site selection were calculated in the previous section. The distance based scoring maps are created with ArcToolbox $\rightarrow$ Spatial Analyst Tools $\rightarrow$ Distance $\rightarrow$ Euclidean Distance tool. For the criteria, 3 classes are created in the GIS according to the distance of the site selection area, and the class intervals are scored between 0 and 5 ( 0 is the lowest, 5 is the highest) (Table 6).

Table 6. Criteria intervals.

\begin{tabular}{|c|c|c|c|}
\hline Subcriteria & $\begin{array}{l}\text { Subcriteria } \\
\text { Values }\end{array}$ & Reference & $\begin{array}{c}\text { GIS Class } \\
\text { Value } \\
(0-5)\end{array}$ \\
\hline \multirow{3}{*}{ C1.1. Settlement Distance (m) } & $1000-2000$ & \multirow{3}{*}{ Güler (2017) } & 3 \\
\hline & $2000-3000$ & & 2 \\
\hline & $3000-5000$ & & 1 \\
\hline \multirow{3}{*}{ C1.2. Highway Distance (m) } & $50-1000$ & \multirow{3}{*}{ Uyan (2013) } & 3 \\
\hline & $1000-3000$ & & 2 \\
\hline & $3000-5000$ & & 1 \\
\hline \multirow{3}{*}{ C1.3. Railways Distance (m) } & $0-3000$ & \multirow{3}{*}{ Atıc1 et al. (2015) } & 5 \\
\hline & $3000-5000$ & & 3 \\
\hline & $5000-10000$ & & 1 \\
\hline \multirow{3}{*}{ C1.4. Airport Distance (m) } & $1000-3000$ & \multirow{3}{*}{ Güler (2017) } & 5 \\
\hline & $3000-5000$ & & 3 \\
\hline & $5000>$ & & 1 \\
\hline \multirow{3}{*}{ C1.5. Distance to Border Crossings (m) } & $50000-75000$ & \multirow{3}{*}{$\begin{array}{l}\text { Opinions of DEMP } \\
\text { experts }\end{array}$} & 3 \\
\hline & $75000-100000$ & & 2 \\
\hline & $100000>$ & & 1 \\
\hline \multirow{2}{*}{$\begin{array}{l}\text { C2.1. Proximity to Disaster Affected } \\
\text { Population (m) }\end{array}$} & $1000-5000$ & \multirow{2}{*}{$\begin{array}{l}\text { Opinions of DEMP } \\
\text { experts }\end{array}$} & 5 \\
\hline & $5000-10000$ & & 3 \\
\hline
\end{tabular}




\begin{tabular}{|c|c|c|c|}
\hline & $10000>$ & & 1 \\
\hline \multirow{3}{*}{ C2.2. Distance to Fault Line (m) } & $18000-20000$ & \multirow{3}{*}{ Sonmez (2011) } & 1 \\
\hline & $20000-40000$ & & 3 \\
\hline & $400000>$ & & 1 \\
\hline \multirow{3}{*}{ C2.3. Landslide Risk } & $0-80$ (very low) & \multirow{3}{*}{$\begin{array}{l}\text { Gaziantep DEMP } \\
(2019 a)\end{array}$} & 5 \\
\hline & 80-160 (low) & & 3 \\
\hline & $160-240$ (medium) & & 1 \\
\hline \multirow{3}{*}{ C.3.1 Slope $\%$} & $0-1$ & \multirow{3}{*}{ Uyan (2013) } & 5 \\
\hline & $1-3$ & & 3 \\
\hline & $3>$ & & 1 \\
\hline \multirow{3}{*}{ C3.2. Flora (m) } & $0-800$ & \multirow{3}{*}{$\begin{array}{l}\text { Opinions of DEMP } \\
\text { experts }\end{array}$} & 1 \\
\hline & $800-10000$ & & 2 \\
\hline & $10000>$ & & 3 \\
\hline \multirow{3}{*}{ C3.3. Elevation (m) } & $290-650$ & \multirow{3}{*}{ Atıc1 et al. (2015) } & 3 \\
\hline & $650-1000$ & & 2 \\
\hline & $1000>$ & & 1 \\
\hline
\end{tabular}

Using the information in Table 6, buffer zones are created for the map layers of all criteria through the Euclidean distance module in ArcGIS. The maps of each criterion regarding to each main criterion are shown in Figures 14 to 16 , respectively.

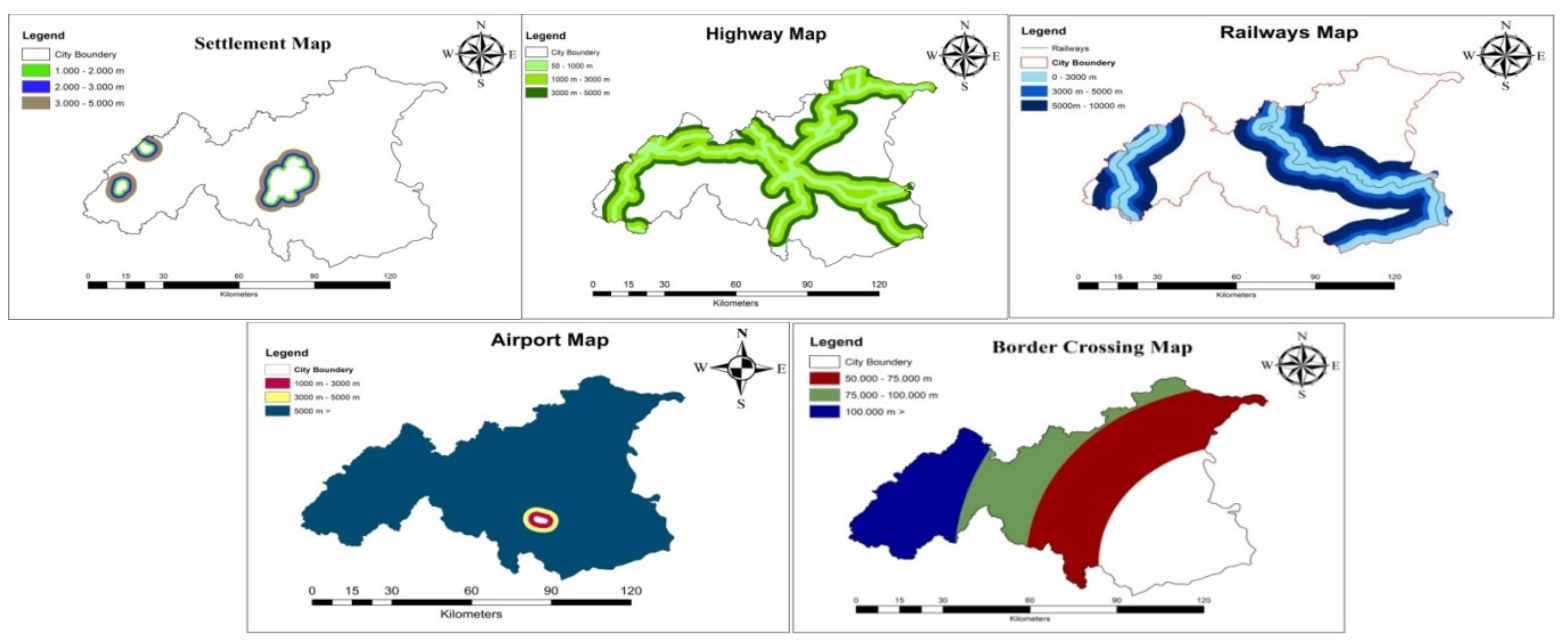

Figure 14. Euclidean distance analysis for the subcriteria of location main criterion. 


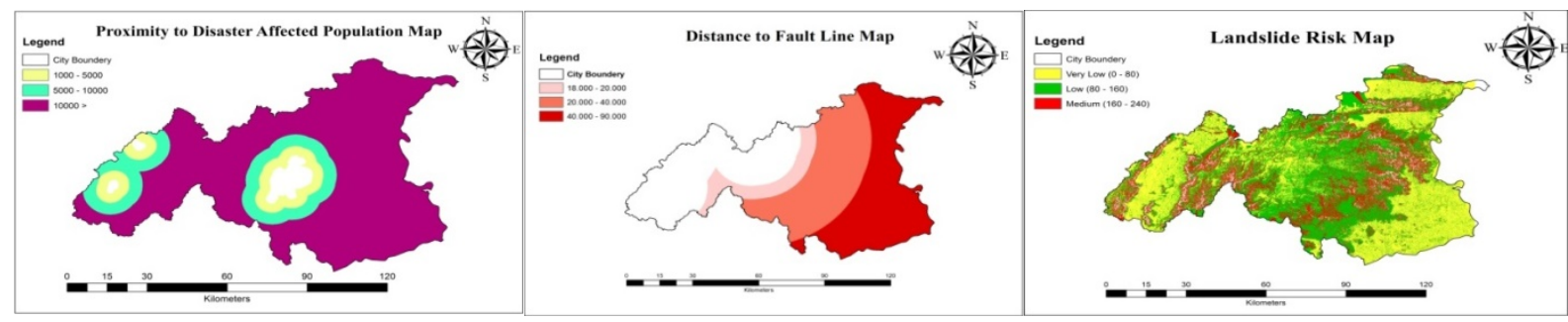

Figure 15. Euclidean distance analysis for the subcriteria of disaster main criterion.

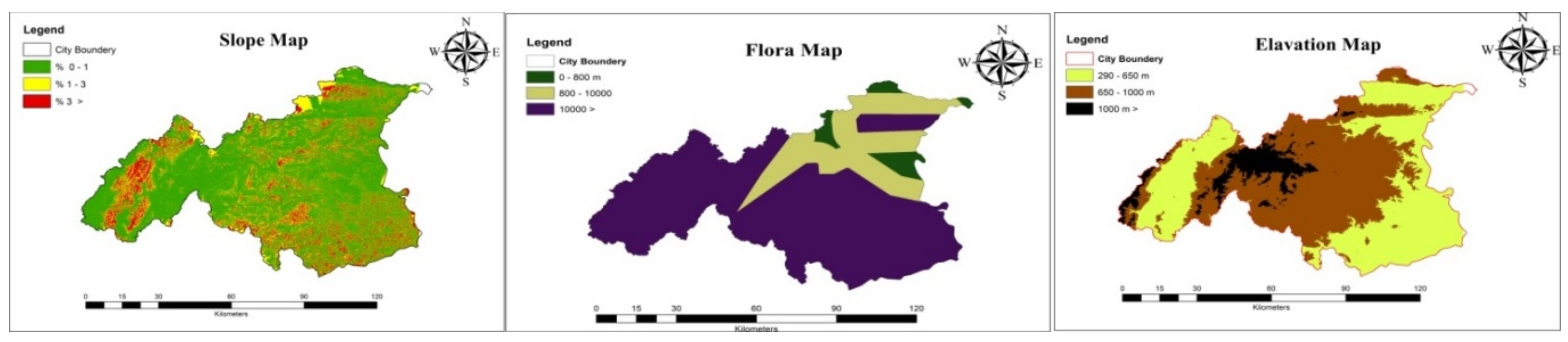

Figure 16. Euclidean distance analysis for the subcriteria of land main criterion.

After the determination of the buffer zones for each criterion, the data created by the reclassification tool were overlapped by the weighted collection method. The weight of each factor was previously calculated by the AHP method. The values of the factors to be used have been determined to influence the analysis of the intervals. The specified weights have been merged with data previously held in the GIS environment. The data obtained as a result of the overlapping process is provided as input to the masking tool. The model builder function of the software is used for the study. The most suitable areas for emergency warehouse are determined by the trapping process which was weighed using the model builder module of the ArcGIS software. The results are found in raster data format with the help of GIS's positional analyses. The map containing the data obtained by running the generated model is shown in Figure 17.

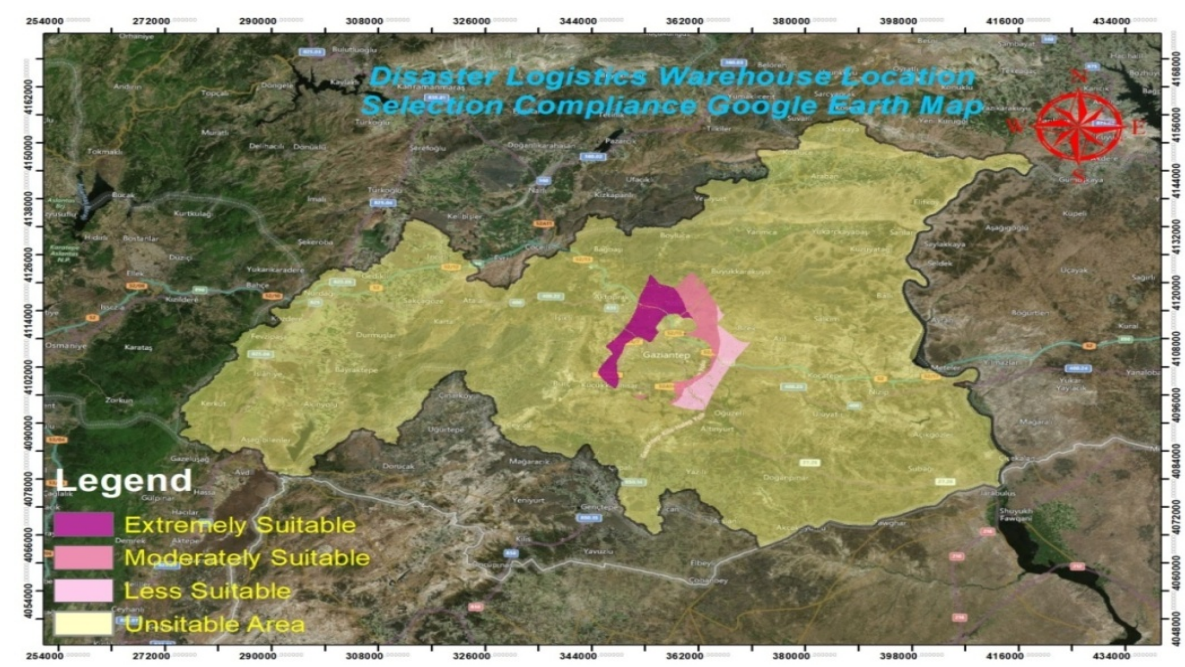

Figure 17. Suitability map after overlapping the layers with weights. 
According to the conformity map formed as a result of the analysis (Figure 17), it is seen that the areas located on the northwest and southwest sides near Gaziantep settlement are very suitable, the areas on the northeast side are moderate, and the areas on the southeast side are less suitable. Apart from these regions, the places within the study area do not seem suitable for the establishment of emergency warehouse.

Fields obtained as a result of the conformity map analysis are divided into four categories as low suitable, moderately suitable, extremely suitable, and unsuitable area. Spatial information of each category is given in Table 7.

Table 7. Spatial information of classes.

\begin{tabular}{|l|r|r|}
\hline Class & Area $\left.\mathbf{( k m}^{\mathbf{2}}\right)$ & Percent $\mathbf{( \% )}$ \\
\hline Low suitable & 68.15 & 1.00 \\
\hline Moderately suitable & 79.12 & 1.16 \\
\hline Extremely suitable & 88.41 & 1.30 \\
\hline Unsuitable & 6.558 .56 & 96.54 \\
\hline
\end{tabular}

According to the results obtained, an area of $88.41 \mathrm{~km}^{2}$ of work area is extremely suitable for the establishment of an emergency warehouse. However, this value only covers $1.3 \%$ of the study area. $1.16 \%$ of the work area is moderately suitable, and $1 \%$ is low suitable. In total, $96.54 \%$ of the work area is strictly unsuitable for the establishment of emergency warehouse. The reason of inappropriate fields being so high stems from the assigned GIS limitation and class values for the criteria used in the study. Figure 18 shows how the appropriate areas detected in ArcGIS.

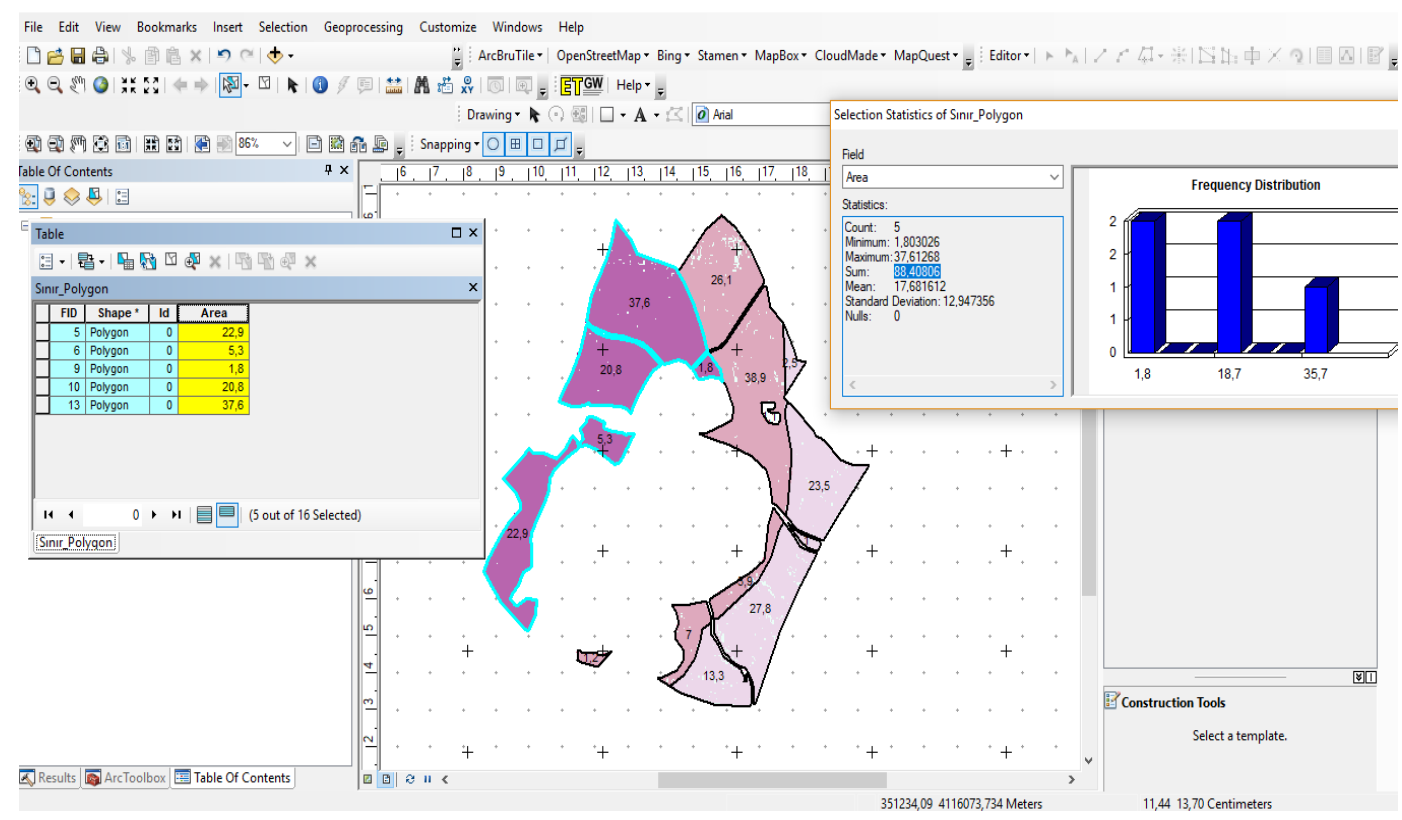

Figure 18. Calculation of extremely suitable areas in ArcGIS. 
The existing DEMP logistics warehouses are built on an area of $10.000 \mathrm{~m}^{2}$ and have $2.400 \mathrm{~m}^{2}$ coverage areas. The land cost criteria are not used in this study, since there is no opportunity to reach sufficient data about land cost in this study area.

But while analyzing the land costs by the AYDES (Disaster Management Decision Support Systems) program, public land and private lands are separated over minimum $10.000 \mathrm{~m}^{2}$ areas required for the establishment of emergency warehouse. Considering the existing DEMP logistics warehouse areas, three alternative sites selected from among the extremely suitable areas identified are described below with their locations.

Alternative\#1. Gaziantep Sehitkamil district is located within the boundaries of Baspinar organized industrial zone, $50 \mathrm{~m}$ away from Adana-Sanliurfa highway. In the inquiry made in the land registry and cadastral information system, the area in question belongs to the treasure, is located on 0 block and 33 plots, and has a size of $972,210 \mathrm{~m}^{2}$. Figure 19 shows the title deed information system image.

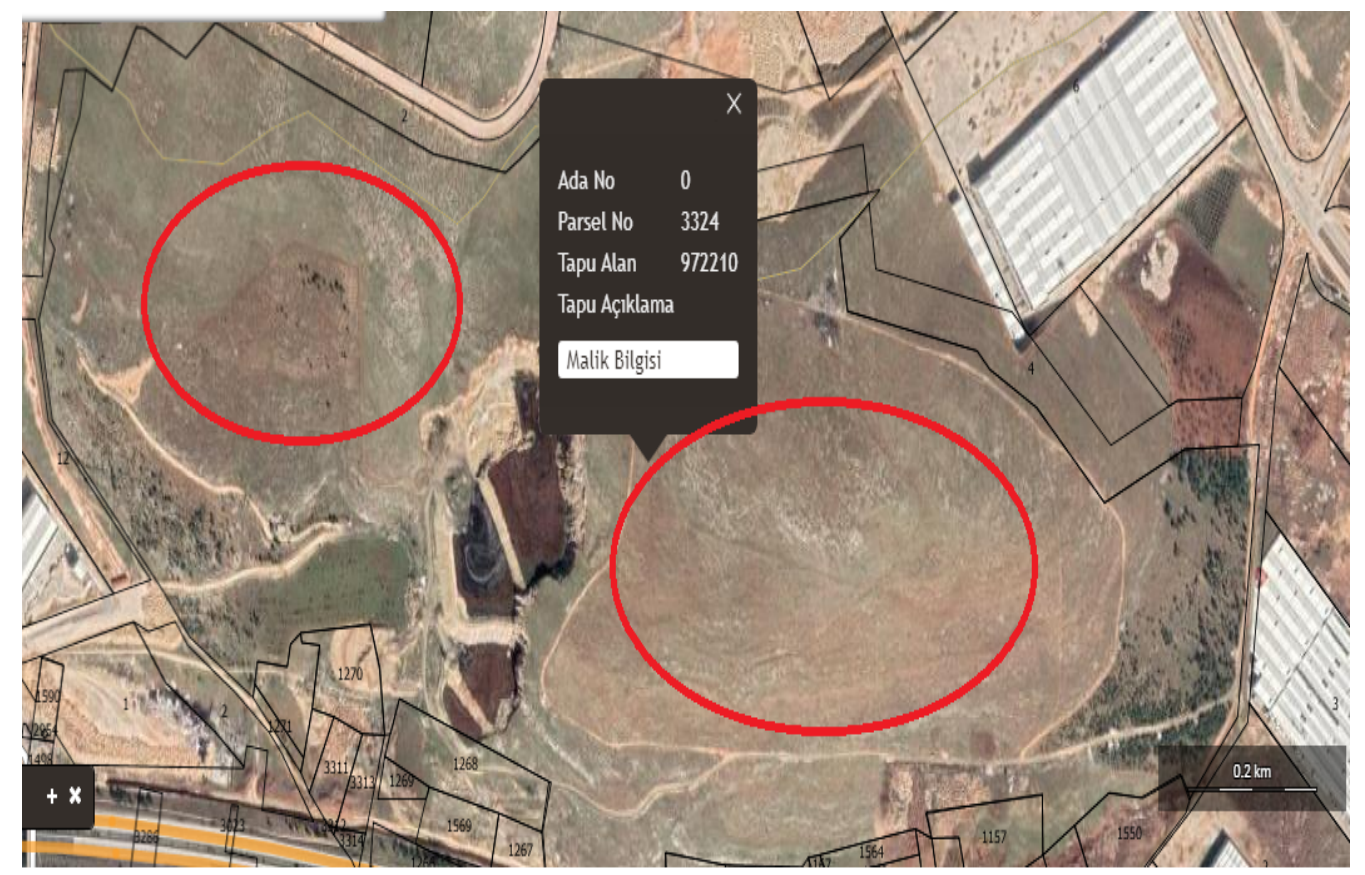

Figure 19. The first alternative site for an emergency warehouse.

Alternative\#2. It is located in Sehitkamil town Yalangoz district, $6 \mathrm{~km}$ away from Adana-Sanliurfa highway and $50 \mathrm{~m}$ away from the northern city public housing project road constructed by Gaziantep Metropolitan Municipality. In the interrogation made in the land registry and cadastral information system, the area in question belongs to the treasure, is located on 110 blocks and 33 plots, and has a size of $42,074 \mathrm{~m}^{2}$. Figure 20 shows the title deed information system image. 


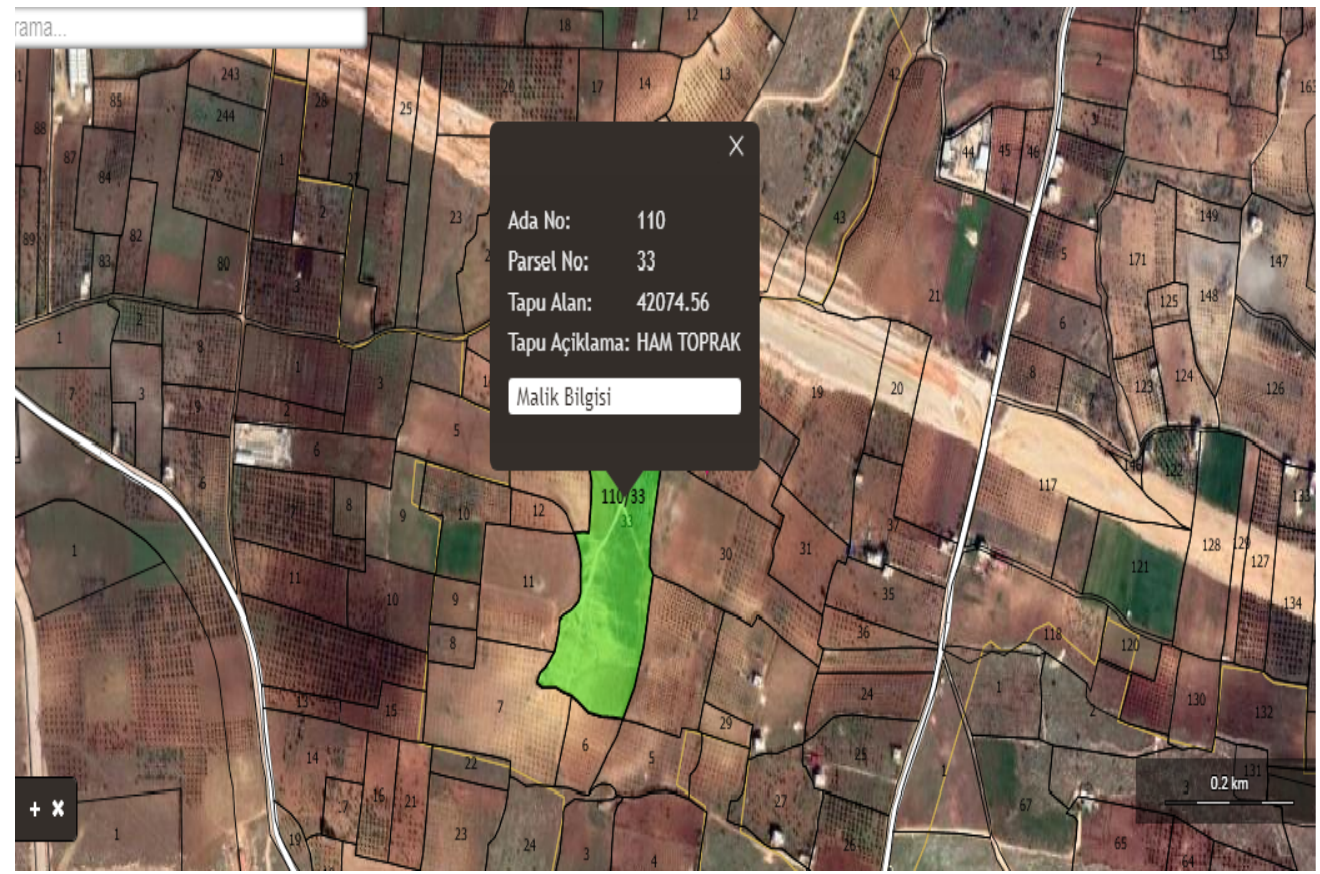

Figure 20. The second alternative site for an emergency warehouse.

Alternative\#3. Sehitkamil town Buyuk Pinar district is 400m away from the ring road. In questioning the land registry and cadastral information system, the area in question is private land; it is located on 0 blocks and 991 plots and has a size of $47,720 \mathrm{~m}^{2}$. Figure 21 shows the title deed information system image.

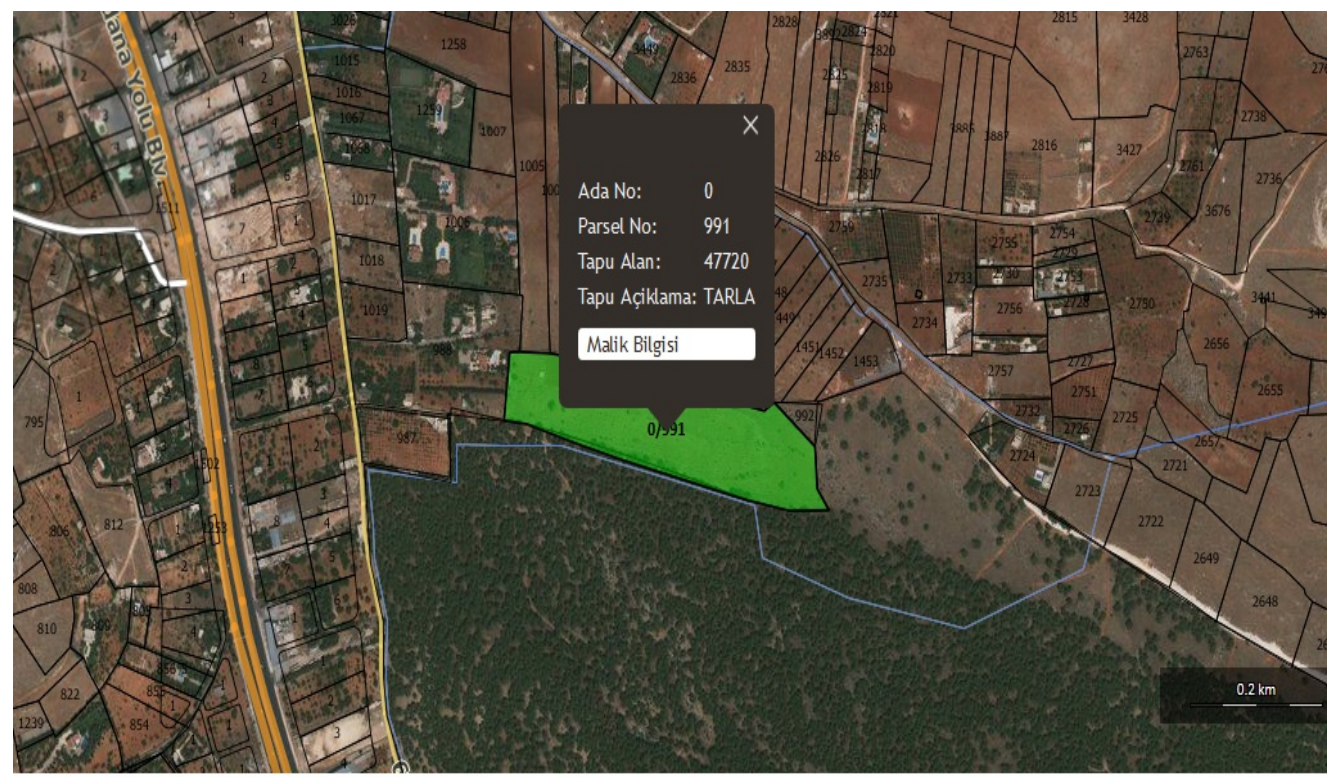

Figure 21. The third alternative site for an emergency warehouse. 
As a result of the evaluations, considering the subcriteria and location, disaster, and the structure of the land, alternative\#1 is selected among the most suitable 3 areas because of the following reasons.

- It has sufficient distance to the settlement,

- It is very close to the highway and railway,

- It complies with potential disasters and the distance restriction distances specified for operation to the fault line,

- It meets the slope, elevation, and flora criteria,

- It is located in the organized industrial zone, and all the infrastructure (electricity, drinking water, sewage, etc.) is present,

- $\quad$ The land belongs to the treasury (reducing installation cost).

After alternative\#1, alternative\#2 may be considered as a second alternative. The reason for this is that alternative\#2 is close to the highway, it complies with the potential disasters and the distance restriction distances determined for the study, it complies with the inclination, elevation, and slope criteria, the infrastructure is available, and it belongs to the treasury. Subsequent to alternative\#2, alternative\#3 can be considered as an alternative field. The reason for considering alternative\#3 as the last alternative area was due to the fact that it is very close to the settlement area, and it is private land.

\subsection{Scenario Analysis and Discussion}

In this part of the study, a scenario analysis is conducted to determine the effects of criteria weights on the problem solution. The new scenario is created by changing the pairwise comparisons as shown in Figure 22. In this way, the AHP results are recalculated as the location criteria " 0.73 ", disaster criteria " 0.19 ", and finally the land structure criteria as " 0.8 ".

\section{Numerical Assessment}

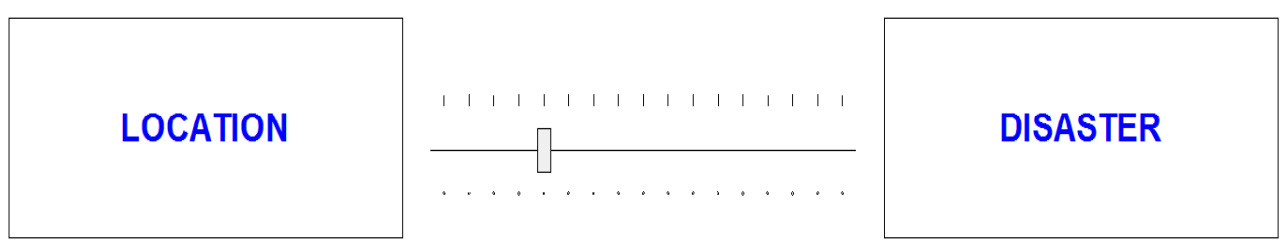

Compare the relative preference with respect to: DISASTER LOGISTICS WAREHOUSE

\begin{tabular}{|l|r|r|}
\hline & LOCATION DISASTER & LAND STR \\
\hline LOCATION & & $\mathbf{5 , 0}$ \\
\hline DISASTER & & 3,0 \\
\hline LAND STRUCTURE & Incon: 0,06 & \\
\hline
\end{tabular}

Figure 22. Matrix of the main criteria for scenario analysis

Figures 23 and 24 show the criteria weights of the main and subcriteria calculated according to the scenario, respectively. 


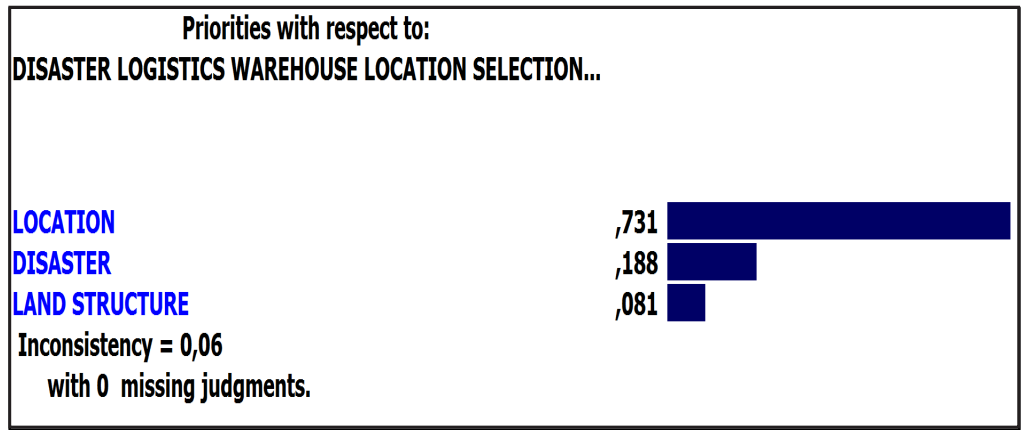

Figure 23. Weights of the main criteria calculated in the scenario study.

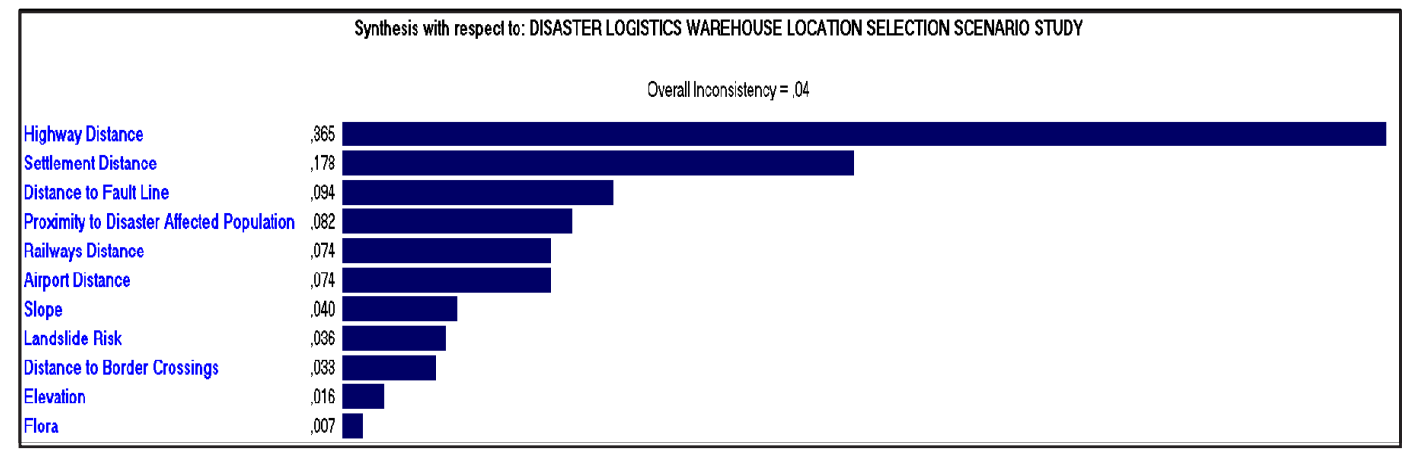

Figure 24. Weights of the subcriteria calculated in the scenario study.

The model is run again by recalculating weights, and the result of the scenario is obtained as shown in Figure 25.

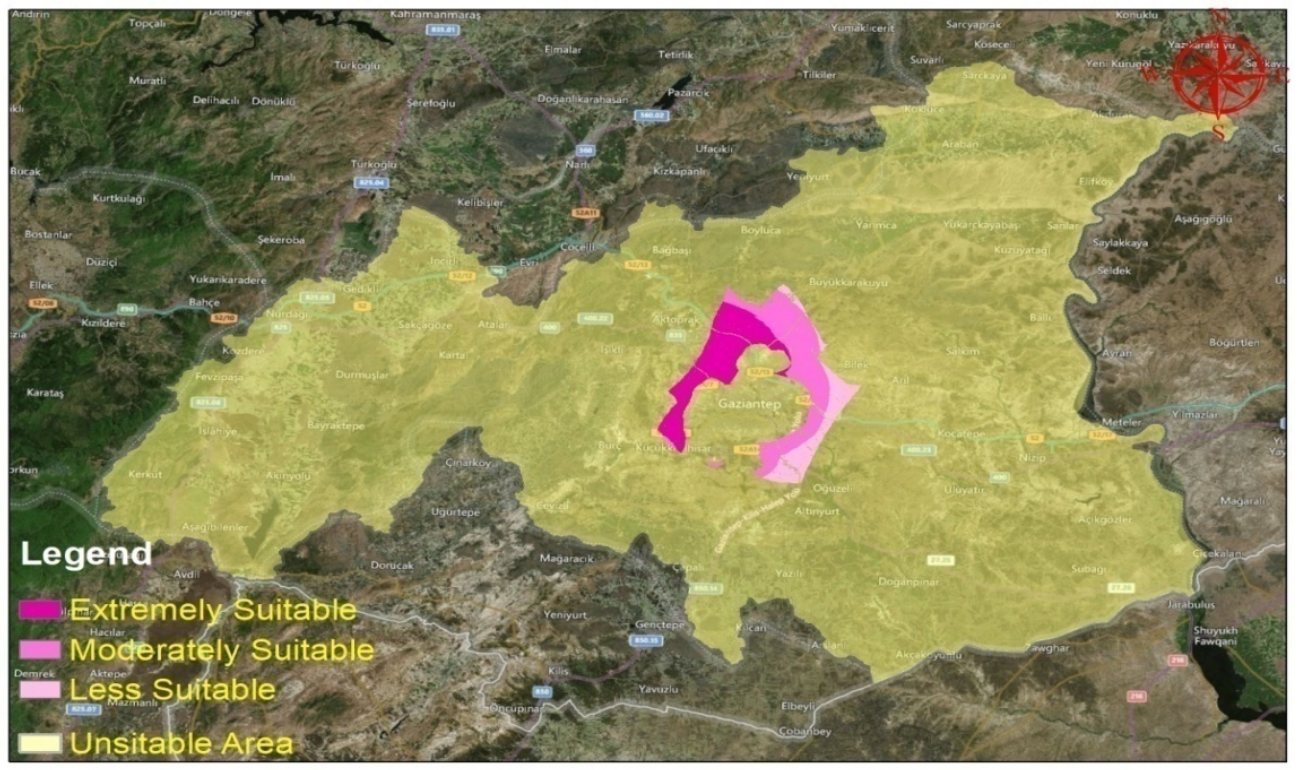

Figure 25. Disaster logistics warehouse scenario compliance map. 
Table 8. Spatial information of the results obtained in the scenario study.

\begin{tabular}{|c|c|c|}
\hline Class & Area $\left(\mathbf{k m}^{\mathbf{2}}\right)$ & Percent (\%) \\
\hline Low suitable & 50.34 & 0.75 \\
\hline Moderately suitable & 105.84 & 1.56 \\
\hline Extremely suitable & 81.21 & 1.19 \\
\hline Unsuitable & $6,556.85$ & 96.50 \\
\hline
\end{tabular}

When the new suitability map is examined in Table 8, the "Extremely suitable" area decreased by $0.11 \%$, while the "Moderately suitable" area increased by $0.4 \%$. On the other hand, the "Low suitable" area decreased by $0.25 \%$ and "Unsuitable" area decreased by $0.04 \%$. So, different results are achieved when the weights are changed, but the changes are minor. So, it is seen that the criteria weights are determined consistently.

\section{CONCLUSION}

In this study, a site selection methodology that uses the AHP with the GIS is proposed for determining the best emergency logistics warehouse site in Gaziantep, Turkey. Firstly, the selection criteria are determined based on the DEMP experts and from the studies in literature and the related data that are obtained. Secondly, the spatial data of each criterion is mapped by using GIS software to determine an availability score to potential locations. Lastly, the criteria are prioritized by using the AHP to generate a suitability map.

According to the results, $88.41 \mathrm{~km}^{2}$ of the study area is determined as "extremely suitable" for emergency logistics warehouses. However, this area only covers $1.3 \%$ of the total study area. Precisely, Gaziantep Şehitkamil district, Başpınar Organized Industrial Zone (Alternative 1) is identified as the most appropriate area for the emergency logistics warehouse. $1.16 \%$ of the study area is determined as "moderately suitable", and $1 \%$ is "low suitable". Strikingly, $96.54 \%$ of the work area is strictly not suitable for emergency logistics warehouses. The reason of inappropriate fields being so high stems from the assigned GIS limitation and class values for the criteria used in the study.

When a sensitivity analysis is conducted by changing the criteria weights, it is seen that "extremely suitable" areas decreased by $0.11 \%$ while "moderately suitable "areas increased by $0.4 \%$. On the other hand, "low suitable" areas decreased by $0.25 \%$ and unsuitable areas decreased by $0.04 \%$. Furthermore, it was seen that the criteria weights of the selection criteria and the restriction values determined for the criteria in GIS analysis are determined accurately and consistently. It is also observed that the proposed model can be used in the studies carried out in different regions with different criteria weights.

To the best of the authors' knowledge, this is the first study in the literature that proposes a scientific approach for emergency warehouse site selection in Turkey. Thus, it is expected that the paper will contribute to the literature and also it will solve a real problem. With an effective plan and implementation for emergency logistics, rapid respond to the disaster can be achieved, and, therefore, possible casualties can be minimized. Also, the costs that are faced during emergency logistics can be minimized. So, Turkey will have great benefits for future disasters. For future studies, the results of proposed method can be compared with another GIS-based MCDM method. Also, the same method can be applied for any region that deals with the same problem. Lastly, fuzzy and robust optimization techniques can be used for more effective solutions as seen in Lotfi et al. (2021a; 2021b). 


\section{REFERENCES}

Achu, A.L., Thomas, J., Reghunath, R., 2020, Multi-criteria decision analysis for delineation of groundwater potential zones in a tropical river basin using remote sensing, GIS and analytical hierarchy process (AHP), Groundwater for Sustainable Development, 10: 1003652.

Amiri, A. B., Asvadi, S. 2015 A prioritization model for locating relief logistic centers using analytic hierarchy process with interval comparison matrix, Knowledge-Based Systems, 86, 173-181.

AYDES. Afet Yönetim ve Destek Karar Sistemleri, 2019. AFAD lojistik depoları. Publication of DEMP. Ankara, Turkey.

Boltürk, E., Onar, S. Ç., Öztayşi, B., Kahraman, C., Göztepe, K., 2016. Multi-attribute warehouse location selection in humanitarian logistics using hesitant fuzzy AHP, International Journal of the Analytic Hierarchy Process, 8 (2), http://dx.doi.org/10.13033/ijahp.v8i2.387

DEMP, Turkish Earthquake Risk Map, 2020. https://deprem.afad.gov.tr/deprem-tehlike-haritasi, Access Date: 04.04.2020

Dhia, H. S., 2020. Determination of warehouse Location for Supporting Emergency Response Operation of Natural Disaster in Padang City, Diploma thesis, Universitas Andalas.

ESRI, Environmental Systems Research Institute, https://www.esri.com.tr/tr-tr/cbs-nedir/genel-bakis, 22.05.2020.

He, J., Feng, C., Hu, D., Liang, L., 2017. A Decision Model for Emergency Warehouse Location Based on a Novel Stochastic MCDA Method: Evidence from China, Mathematical Problems in Engineering, doi:10.1155/2017/7804781

IFRC, Disaster and crisis management, https://www.ifrc.org/en/what-we-do/disaster-management/ Access Date: 12.04 .2020

Karimi, H., Amiri, S., Huang, J., Karimi, A., 2019. Integrating GIS and multi-criteria decision analysis for landfill site selection, case study: Javanrood County in Iran. International Journal of Environmental Science and Technology, 16, 7305-7318.

Kemaloglu, M., 2015. Historical and Legal Development of Disaster Managementin Turkey Akademik Bakis Dergisi, 52, 126-147.

Kılcı, F. 2012. A Decision Support System for Shelter Site Selection with GIS Integration: Case for Turkey, Published Master Thesis, Bilkent University, Ankara.

Liu, C., Chen, Z., Gong, Y. 2013. Site selection of emergency material warehouse under fuzzy environment. Journal of Central South University, 20, 1610-1615.

Lotfi, R., Mehrjerdi, Y. Z., Mardani, N. 2017. A multi-objective and multi-product advertising billboard location model with attraction factor mathematical modeling and solutions. International Journal of Applied Logistics, 7(1), 64-86.

Lotfi, R., Mostafaeipour, A., Mardani, N., Mardani, S.,2018. Investigation of wind farm location planning by considering budget constraints, International Journal of Sustainable Energy, 37:8, 799-817,

Lotfi, R., Mardani, N., Weber, G. W., 2021a. Robust bi-level programming for renewable energy location, International Journal of Energy Research, 45(5), 7521-7534.

Lotfi, R., Yadegari, Z., Hosseini, S.H., Khameneh, A.H., Tirkolaee, E.B., Weber, G.-W. 2021b. A robust time-cost-quality-energy-environment trade-off with resource-constrained in project management: A case study for a bridge construction project,Journal of Industrial \& Management Optimization, doi: 10.3934/jimo.2020158. 
Ma, Y., Xu, W., Qin, L., Zhao, X. 2019. Site Selection Models in Natural Disaster Shelters:A Review, Sustainability, 11, 399; doi:10.3390/su11020399

Malczewski, J., 2006. GIS-based multi-criteria decision analysis: A survey of the literature, International Journal of Geographical Information Science, 10(7), 703-726.

Ocampo, L., Genimelo, G. J., Lariosa, J., Guinitaran, R., Borromeo, P. J., Aparente, M. E., Capin, T., Bongo, M., 2020. Warehouse location selection with TOPSIS group decision making under different expert priority allocations,Engineering Management in Production and Services, 12, 20-39.

Roh, S. Y., Jang, H. M., Han, C. H., 2013. Warehouse Location Decision Factors in Humanitarian Relief Logistics, The Asian Journal of Shipping and Logistics, 29 (1), 103-120.

Roh, S. Y., Shin, Y. R., Seo, Y. J., 2018. The Pre-positioned Warehouse Location Selection for International Humanitarian Relief Logistics, The Asian Journal of Shipping and Logistics, 34(4), 297-307.

Saaty T.L., 1980. The analytic hierarchy process, McGraw-Hill, New York.

Song, S., Zhou, H., Song W, 2019. Sustainable shelter-site selection under uncertainty: A rough QUALIFLEX method, Computers \& Industrial Engineering, 128, 371-386.

Timperio, G., Panchal, G. B., Samvedi, A., Goh, M., De Souza, R. 2017. Decision support framework for location selection and disaster relief network design, Journal of Humanitarian Logistics and Supply Chain Management, 7 (3), 222-245.

Trivedi A, Singh A., 2017. Prioritizing emergency shelter areas using hybrid multi-criteria decision approach: A case study. Journal of Multi-Criteria Decision Analysis, 24, 133-145.

TSI, Turkish Statistical Institute 2018. http://tuik.gov.tr/PreTablo.do?alt_id=1047, 22.05.2020

Turğut, B. T., Taş, G., Herekoğlu, A. 2011. A fuzzy AHP based decision support system for disaster center location selection and a case study for Istanbul, Disaster Prevention and Management, 20 (5), 499-520.

CovidTurkey, 2020. Coronavirus risk map of Turkey, https://www.sozcu.com.tr/2020/gundem/son-dakikabakan-koca-son-verileri-acikladi-5821963/ Access date: 19.05.2020.

WHO (World Health Organization), 2020. Novel coronavirussituation report 3. https://www.who.int/docs/default-source/coronaviruse/situation-reports/20200204-sitrep-15-ncov.pdf Access date: 10.05 .2020 